\title{
nature
}

15 July 2004 Volume 430 Issue no 6997

\section{A true test of leadership}

Muammar Gaddafi, the Libyan leader, can demonstrate his aspirations to statesmanship by using the occasion of the XV International AIDS Conference to free health workers unjustly sentenced to death for infecting patients with HIV.

V alya Chervenyashka; Snezhana Dimitrova; Nasya Nenova; Valentina Siropulo; Kristiana Valcheva. These five Bulgarian nurses, along with Ashraf Ahmad Jum'a, a Palestinian doctor, were sentenced to death by firing squad by a Libyan court on 6 May. Their crime: deliberately infecting 400 children with HIV at the al-Fateh Hospital in Benghazi in 1998, causing the death of 40 .

The convicted health workers, who have languished in prison since 1999, will appeal. They need our support. Amnesty International and other human-rights groups have already denounced the convictions, arguing that confessions were extracted by torture.

The convictions also run counter to the scientific evidence. Luc Montagnier, whose group at the Pasteur Institute in Paris discovered HIV, and Vittorio Colizzi, an AIDS researcher at Rome's Tor Vergata University, were asked by the Libyan government to examine the scientific evidence. Their report, submitted in April, should have removed any suggestion that the accused were guilty.

Montagnier and Colizzi's genetic analysis of viruses from the infected children indicated that many of them were infected long before the Bulgarian nurses set foot in Libya in March 1998; some of the infections probably dated as far back as 1994. The children also showed a high incidence of co-infection with hepatitis B and C, suggesting that the underlying problem was an infection from a common source, spread by poor hospital hygiene. This is a tragedy, but such problems aren't unique to Libya.

The analyses also showed that the infections were caused by subtypes of A/G HIV-1 - a recombinant strain common in central and west Africa, and known to be highly infectious. The samples showed little variation, again suggesting a common origin, probably spread from an already-infected patient via dirty catheters and syringes.
Another nurse, who reported accidentally injecting herself while handling blood samples, carried an almost identical virus.

Montagnier argues that, in a further travesty of justice, the judgment was based at least partly on a mistranslation from English to Arabic of the term 'recombinant'. This term, used by Montagnier and Colizzi to mean the natural recombination of wild viruses, was translated in the judgment to mean a 'genetically modified' virus, says Montagnier, implying human manipulation.

The verdict slaked the mob's thirst for vengeance, being greeted with rejoicing in Benghazi. But it should chill the blood of anyone who cares for justice and the use of scientific evidence in its name.

In a letter earlier this month, Montagnier and Colizzi, backed by leading virologists and physicians, asked Libyan leader Muammar Gaddafi to commute the death sentences, dismiss the cases and review how the trial was conducted. Montagnier wrote a second letter to Gaddafi on 6 July, arguing that clemency "will certainly magnify the good image of Libya in the world".

Further pressure is warranted. After decades as a pariah, Libya is now taking steps to rejoin the international community. Gaddafi helped whip up domestic feeling against the health workers, arguing in 2001 that their actions were part of a plot orchestrated by the CIA and Israel's Mossad. By recognizing the injustice that has since been done, he could send a clear signal that he wants to put his past behind him.

Opening the XV International AIDS Conference in Bangkok, Thailand, on 11 July, United Nations secretary-general Kofi Annan argued that defeating HIV requires leadership at the highest level. Gaddafi has a chance to show the world that he now understands that true leadership means embracing justice, compassion and a respect for scientific evidence.

\section{Science on show in Stockholm}

\section{Introducing the first Europe-wide meeting for scientists and science's stakeholders.}

W hy do science's messages so often get lost in the midst of media coverage of controversies such as genetically modified crops? If they didn't, would a regulatory process that involved more public participation help or hinder technological development? How can we separate hype from reality in fields such as stem-cell research and robotics? What are the neural underpinnings of our awareness of action? And, by the way, how can light be brought to a standstill?

The chances are that, as a Nature reader, you are interested in all of these questions. They and many others are being addressed in Stockholm, Sweden, on 25-28 August, at a meeting for scientists, policymakers, the media and the wider public: the EuroScience Open Forum 2004. For the conference programme, see www.esof2004.org.

Nature should declare its interest, having supported the forum since its conception (see Nature 423,$571 ; 2003$ ). We are organizing two sessions: one on the prospects and challenges presented at the European level by infectious diseases; the other examining the predictability or otherwise of extreme climatic events in Europe. We are also organizing talks and workshops on careers themes, including one of universal interest, on how to negotiate your salary.

There are obvious parallels with the annual meeting of the American Association for the Advancement of Science (AAAS). In a cynical age, some observers have questioned the need for such large gatherings. And there are bound to be grumbles about holding the inaugural European meeting of this type at the tail-end of the holiday season. But if nothing else, the AAAS meeting provides a valuable focus for mainstream media treatment of issues of scientific importance. If the EuroScience forum can achieve a reasonable fraction of this coverage, and a measure of public participation, it will be a welcome addition to the annual meetings calendar.

As its name suggests, the meeting includes a specifically European agenda, with sessions that address both professional issues (such as the commercialization of Europe's universities) and topics of broader topicality (for example, the continent's transformation to a lowcarbon economy). But science is global, and so are most of the topics that will be discussed in Stockholm. We hope to see you there. 